\title{
4. INITIAL COIN OFFERING JAKO NOWA FORMA FINANSOWANIA I INWESTYCJI
}

\author{
(iD) Katarzyna Włosik \\ Uniwersytet Ekonomiczny w Poznaniu \\ katarzyna.wlosik@ue.poznan.pl \\ https://doi.org/10.18559/978-83-8211-083-8/4
}

\section{Initial coin offering as a new form of financing and investing}

Abstract: This part of the monograph is related to initial coin offering - a mechanism that allows blockchain-based companies or projects to obtain financing. In return for financial support, ICO participants are offered different types of digital tokens - payment, utility or investment tokens. The chapter contains the systematization of issues related to ICO and tokens as well as a description of stages of initial coin offering. The SWOT analysis of ICO highlights the strengths and opportunities related to ICO - inter alia the possibility of portfolio diversification and the limited access for individual investors to early-stage investments (apart from ICO). Also the weaknesses of initial coin offering (e.g. the need to prepare a due diligence by an investor) and associated risks (e.g. regulatory uncertainty) are considered. Moreover, the author identifies research areas related to ICO. They include, among others, the identification of ICO success factors and the identification of factors affecting the rates of return on tokens.

Keywords: ICO, initial coin offering, token.

\subsection{Wstęp}

W 2008 roku osoba lub grupa osób skrywających swoją tożsamość pod pseudonimem Satoshi Nakamoto opublikowała koncepcję bitcoina. Według przedstawionych w niej założeń miała to być wersja elektronicznego pieniądza oparta na sieci peer-to-peer $(\mathrm{P} 2 \mathrm{P})^{1}$, dzięki której możliwe byłoby przesyłanie płatności online między dwoma podmiotami, bez pośrednictwa jakiejkolwiek instytucji finansowej (Nakamoto, 2008)². Jego protokół w dużej mierze opiera się na istniejących już

${ }^{1}$ Sieć posiadająca architekturę peer-to-peer (P2P) nie ma specjalnych węzłów (uczestników) - komputery funkcjonują jako równorzędne jednostki, jednocześnie świadczące i korzystające z usług sieciowych (Antonopoulos, 2018, s. 185).

${ }^{2}$ Obecnie dominuje przekonanie, że bitcoin nie wypełnia ekonomicznych funkcji pieniądza (między innymi Kubát, 2015; EBC, 2015; Marszałek, 2019; Sławiński, 2019) i posiada cechy waloru spekulacyjnego (Baur, Hong i Lee, 2018). 
wcześniej rozwiązaniach - przede wszystkim na sieci peer-to-peer i kryptografii, ale zostały one uzupełnione blockchainem ${ }^{3}$. Podczas gdy spektakularne wzrosty i spadki cen bitcoina przyniosły mu duży i stosunkowo szybki rozgłos, leżąca $\mathrm{u}$ jego podstaw technologia blockchain zaczęła powoli przykuwać uwagę reprezentantów różnych branż (Lehman, 2016, s. 9). Technologia blockchain napędziła powstawanie nowych innowacji i produktów finansowych. Jednym z jej najbardziej znanych zastosowań w finansach jest initial coin offering (ICO). Poziom wykorzystania ICO zmienił swój status od ,zbyt małego, by się nim przejmować” (too small to care), do ,zbyt dużego, by go zignorować” (too big to ignore) (OECD, 2019, s. 3). Nie zignorowano go również w tej książce, stąd poniżej przybliżono zagadnienie ICO. W rozdziale będą realizowane trzy cele, którymi są:

- systematyzacja zagadnień dotyczących idei ICO i tokenów oraz etapów ICO;

- przedstawienie analizy SWOT dla ICO i tokenów;

- wskazanie obszarów badań naukowych związanych z ICO.

W zakończeniu podsumowano przedstawione rozważania.

\subsection{Istota ICO i tokenów ${ }^{4}$}

ICO (initial coin offering) ${ }^{5}$, określane również mianem oferty lub oferowania tokenów (token offering), jest mechanizmem pozwalającym pozyskać finansowanie przez firmy lub projekty oparte na technologii blockchain. Firma lub projekt otrzymuje finansowanie i w zamian oferuje uczestnikom ICO cyfrowe tokeny. Transakcja ta jest zawierana za pomocą tzw. inteligentnego kontraktu (smart contract $)^{6}$, który autonomicznie egzekwuje wymianę środków między podmiotem chcącym pozyskać finansowanie a podmiotami, które tego finansowania udzielają (Adhami i Giudici, 2019). ICO swoją nazwą nawiązuje do pierwszej oferty publicznej na rynku akcji, a więc IPO - initial public offering (Cohney, Hoffman, Sklaroff i Wishnick, 2019). Stanowi nową metodę pozyskiwania kapitału na

\footnotetext{
${ }^{3}$ Blockchain jest to rozproszona baza danych, zawierająca w sobie rosnącą ilość informacji, które są zapisane w formie rekordów. Są one grupowane w bloki i powiązane ze sobą - każdy kolejny blok zawiera oznaczenie czasu, informujące o tym kiedy powstał, oraz odnośnik do poprzedzającego go bloku, który jest zaszyfrowanym streszczeniem jego zawartości (tzw. hash) (Piech, 2016, s. 5).

${ }^{4}$ Treści przedstawione w tym podrozdziale pojawiły się już w: (Włosik, 2021, pkt 2.3 i 4.1.1).

${ }^{5}$ Angielska wersja tego pojęcia jest często stosowana w publikacjach polskojęzycznych. $\mathrm{Z}$ tego względu w niniejszym rozdziale również będzie ona stosowana.

${ }^{6}$ Inteligentne kontrakty (smart contracts) są to protokoły komputerowe, które automatyzują transakcje polegające na wymianie środków pomiędzy przedsiębiorcą a inwestorem. Potencjalnie mogą one doprowadzić do całkowitego wyeliminowania pośredników (Momtaz, 2020).
} 
realizację przedsięwzięć na wczesnym etapie rozwoju (ventures) i jest alternatywą dla takich bardziej tradycyjnych źródeł finansowania start-up'ów, jak venture capital czy środki tzw. aniołów biznesu (Howell, Niessner i Yermack, 2020).

Jak zauważa Momtaz (2021b), w większości analiz określenia ICO oraz sprzedaż tokenów są używane wymiennie, choć pierwsze z tych pojęć może być nieco mylące. W większości przypadków przy sprzedaży tokenów ich maksymalna podaż jest z góry ustalona. Oznacza to, że sprzedaż tokenów jest jednorazowa - nie ma pierwotnej oferty, po której następują kolejne. $Z$ tego względu, według Momtaza (2019; 2021b), zamiast ICO powinno się stosować określenie oferta (sprzedaży) tokenów (token offering). Tak jednak nie jest i pojęcia sprzedaż tokenów oraz ICO bywają stosowane zamiennie (na przykład Momtaz, 2019).

Można również zaobserwować, że w ostatnim czasie określenie ICO jest wykorzystywane w odniesieniu do tokenów użytkowych (Liu i Wang, 2019b; Momtaz, 2019), natomiast pojęcie sprzedaż tokenów jest używane w szerszym kontekście (Momtaz, 2019). Z kolei Liu i Wang (2019b) zauważają, że w praktyce rynkowej w odniesieniu do emisji tokenów inwestycyjnych (security tokens) jest stosowany termin STO - security token offerings. Autorzy ci zdecydowali się jednak na wykorzystanie określenia ICO do opisu sprzedaży zarówno tokenów użytkowych, jak i inwestycyjnych.

Wspomniane tokeny to zabezpieczone kryptograficznie aktywa cyfrowe (Howell $\mathrm{i}$ in., 2020). Obecnie naukowcy wyróżniają dwie lub trzy podstawowe grupy tokenów. W pierwszym przypadku to tokeny użytkowe i inwestycyjne (między innymi Houben i Snyers, 2018; Block, Groh, Hornuf i Vismara, 2020). Do drugiej grupy dodawane są kryptowaluty (takie podejście stosują między innymi Liu i Wang (2019a); Momtaz (2020); Howell i in. (2020)).

Tokeny inwestycyjne (investment/security tokens) to tokeny, które swoją konstrukcją przypominają tradycyjne aktywa inwestycyjne - na przykład obligacje lub akcje. Reprezentują prawa ich posiadacza względem podmiotu, który dokonał ich emisji. Na przykład mogą być to prawa do dywidendy lub prawa głosu (Houben i Snyers, 2018, s. 23-24). Tokeny tego typu podlegają zwykle regulacjom dotyczącym papierów wartościowych (Momtaz, 2020).

Tokeny użytkowe (utility tokens) to z kolei tokeny, które mogą zostać wykorzystane do zakupu określonych dóbr lub usług. Nie są one jednak środkiem wymiany ogólnego przeznaczenia, gdyż generalnie mają być wykorzystywane wyłącznie na platformie, do której obsługi są stworzone (Houben i Snyers, 2018, s. 23-24). Nie dają ich posiadaczowi praw własności. Są popularne ze względu na dotychczasowy niski poziom ich uregulowania w wielu jurysdykcjach (Momtaz, 2020).

Kryptowaluty są określane również jako tokeny kryptowalutowe (cryptocurrency tokens), tokeny płatnicze (payment tokens) lub monety (coins) (Howell i in., 2020; Momtaz, 2020). Jak wiemy z poprzednich rozdziałów, ich najbardziej znanym przykładem jest bitcoin. Przez niektórych badaczy kryptowaluty są uważane 
za tokeny, które służą za środek przechowywania wartości lub środek wymiany. Jak zauważa Momtaz (2019), z technicznego punktu widzenia kryptowaluty różnią się od tokenów tym, że opierają się na swoich własnych blockchainach, natomiast tokeny wykorzystują już istniejące blockchainy. Ze względu na tę cechę różnicującą należy stwierdzić, że większość kryptowalut to tokeny. Wielu autorów używa jednak tych terminów zamiennie (Momtaz, 2019).

Powyższe kategorie nie wykluczają się wzajemnie. Z tego względu można mówić o tokenach hybrydowych, które łączą w sobie cechy tokenów z wymienionych grup (Dobrauz-Saldapenna i Klebeck, 2019).

\subsection{Charakterystyka kolejnych etapów ICO7}

W większości przypadków ICO jest złożone z czterech głównych etapów (Liu i Wang, 2019b):

- etapu wstępnego,

- przedsprzedaży tokenów,

- właściwego ICO,

- rozwoju projektu opartego na technologii blockchain oraz wprowadzenia tokenów przez emitentów na platformy obrotu kryptoaktywami.

Etap wstępny obejmuje: planowanie strategiczne projektu, przygotowania prawne i zgromadzenie wymaganych dokumentów, projektowanie i stworzenie tokenów oraz przeprowadzanie akcji marketingowej (Liu i Wang, 2019b).

Większość tokenów powstaje na podstawie blockchainu Ethereum. Odbywa się to zgodnie z protokołem Ethereum request for comment 20 (ERC 20). Dostarcza on zbioru reguł, które muszą zostać uwzględnione podczas tworzenia tokenu. Na podstawie danych ze stycznia 2019 roku można stwierdzić, że w ten sposób powstało 165 tys. tokenów. Wystarczy pobrać kod ze strony internetowej Ethereum, a następnie dokonać modyfikacji różnych parametrów, takich jak całkowita liczba tokenów. Łatwość, z jaką można stworzyć tokeny przy pomocy Ethereum, była zasadniczym czynnikiem odpowiadającym za wzrost liczby ICO, ponieważ sprawia, że proces ten jest krótszy i mniej techniczny (Momtaz, 2020).

Gdy emitent utworzy już wszystkie tokeny, musi ustalić, jaką ich część wykorzysta w ICO do zgromadzenia środków. Analizy empiryczne wskazują, że jest to w przybliżeniu od 54 do 61\% (Liu i Wang, 2019b).

Decydując się na sprzedaż tokenów, emitenci muszą również podjąć decyzje dotyczące tzw. minimalnego limitu (soft cap) oraz maksymalnego limitu (hard cap).

${ }^{7}$ Treści przedstawione w tym podrozdziale są rozwinięciem wywodów zawartych w: (Włosik, 2021, pkt 4.1.1). 
Pierwszy limit to minimalna kwota środków, którą organizator sprzedaży tokenów chciałby zebrać. Jeśli mu się to nie uda, to środki są zazwyczaj zwracane inwestorom. Jednak wprowadzanie tego limitu nie jest obecnie zbyt powszechne. Z kolei drugi limit określa maksymalną kwotę środków, którą emitent chciałby zebrać poprzez ICO. Badania empiryczne wskazują, że zwykle limit ten zawiera się w przedziale od 43 do $93 \mathrm{mln}$ USD, jednak rozkład wartości cechuje wysoka asymetria, a mediana wartości kształtuje się na poziomie 20-23 mln USD (Liu i Wang, 2019b). Ponadto przy emisji tokenów należy określić, czy twórców projektu i wczesnych inwestorów będzie obowiązywał okres „,zamrożenia” środków (lock-up period), w czasie którego nie będą mogli odsprzedać swoich tokenów (Cohney i in., 2019).

Istotnym elementem etapu wstępnego są działania marketingowe związane z ICO. Rozpoczynają się one niemal w tym samym momencie co sam projekt. Początkowe aktywności reklamowe obejmują między innymi stworzenie profesjonalnej strony internetowej, wykorzystanie mediów społecznościowych czy kanałów na komunikatorach umożliwiających kontakt między inwestorami (na przykład Telegram). Gdy zbliża się termin ICO lub przedsprzedaży tokenów (pre-ICO), reprezentanci zespołu tworzącego projekt wyruszają na spotkania z potencjalnymi inwestorami i publikowany jest tzw. white paper (Momtaz, 2020). Jest to główny dokument tworzony przy ICO, który swoją formą przypomina nieco prospekt emisyjny wykorzystywany przy pierwszej ofercie publicznej na rynku akcji. White papers mogą się bardzo różnić, jednak zwykle zawierają informacje dotyczące takich aspektów, jak: model biznesowy przedsięwzięcia, jego aspekty techniczne, szczegółowe cechy tokenów (ich typ, mechanizm alokacji i dystrybucji), przeznaczenie zgromadzonych środków, emitenci tokenów, status prawny, czas trwania ICO, przewidywana liczba tokenów wprowadzonych do obiegu, kryptowaluty przyjmowane w zamian za tokeny, harmonogram realizacji projektu (Liu i Wang, 2019b).

W przypadku wielu projektów organizowana jest przedsprzedaż tokenów (pre-ICO). Są one wówczas sprzedawane pierwszym inwestorom (oryg. early investors) po cenie niższej niż we właściwym ICO, by zachęcić ich do ulokowania środków w dany projekt. Powodem, dla którego jest organizowana taka przedsprzedaż, bywa często chęć zgromadzenia środków na pokrycie kosztów przeprowadzenia właściwego ICO. Ponadto stanowi ona źródło informacji od potencjalnych inwestorów, które pozwalają określić odpowiednią cenę tokenów oraz ogólną sumę środków możliwych do zebrania w czasie ICO. Dzięki temu możliwe jest zwiększenie efektywności właściwego ICO (Momtaz, 2020). Oferta ta jest skierowana do określonych inwestorów - przede wszystkim do inwestorów instytucjonalnych oraz rynku venture capital (Liu i Wang, 2019b), a także do inwestorów uprzywilejowanych i akredytowanych (Benedetti i Kostovetsky, 2021). Badania empiryczne wskazują, że przedsprzedaż jest dość częstą praktyką (Liu 
i Wang, 2019b) - w próbie Adhami'ego i in. (2018) to 34\% projektów, Benedettiego i Kostovetsky'ego (2021) - 40\% analizowanych ICO, a Momtaza (2020) - 44\%.

Właściwe ICO może mieć zróżnicowany czas trwania. Zdarza się, że niektóre ICO kończą się w przeciągu jednego dnia lub nawet jeszcze szybciej, a inne mogą trwać rok, a nawet dłużej. Sam proces przebiegu ICO jest stosunkowo prosty. Tworzony jest adres, na który mają zostać przelane środki. Emitenci określają również, które kryptowaluty (możliwe że również waluty tradycyjne) będą przyjmowane jako zapłata za tokeny. W kolejnym kroku inwestorzy przesyłają środki na utworzony wcześniej i wskazany adres, a następnie otrzymują w zamian odpowiednią liczbę tokenów (Momtaz, 2020). ICO przebiega więc bez pośredników. Z tego względu due dilligence leży w indywidualnej gestii inwestora (Block i in., 2020).

Huang i in. (2020) na podstawie badania grupy 915 ICO dochodzą do wniosku, że ICO są częściej przeprowadzane w państwach, których organy przedstawiają swoje intencje odnośnie do regulacji dotyczących funkcjonowania ICO. Występują one natomiast rzadziej w państwach, w których organy nie podejmują żadnych działań w tym zakresie lub w których wprowadzają zakaz przeprowadzania ICO. Ponadto autorzy zauważają, że ICO występują częściej w państwach z rozwiniętym systemem finansowym i publicznym rynkiem papierów wartościowych oraz wykorzystujących zaawansowane technologie cyfrowe. Wyniki ich analizy wskazują również, że ICO są częstsze w państwach, w których znajduje się więcej platform crowdfundingowych (Huang, Meoli i Vismara, 2020). Ze względu na ograniczenia natury prawnej obywatele niektórych jurysdykcji mogą jednak nie móc brać udziału w ICO (Liu i Wang, 2019b). Rhue (2018), analizując pulę 435 ICO, stwierdza, że obywatele USA nie mogli uczestniczyć w 33\% projektach, a obywatele Chin - w $27 \%$.

Motywy skłaniające inwestorów do lokowania środków w ICO są różnorodne. Niektórzy z nich chcą być pierwszymi użytkownikami (early adopters), kupić tokeny wcześniej po niższej cenie i korzystać z nich w późniejszym czasie. Inna grupa uczestników ICO może się składać z długoterminowych inwestorów i zdecydować się na zakup tokenów ze względu na silną wiarę w sukces projektu. Niektórzy mogą również podejmować działalność spekulacyjną i nabyć tokeny po to, by odsprzedać je po wyższej cenie w niedalekiej przyszłości (Chen, 2018). $\mathrm{Na}$ podstawie analizy grupy 517 z nich, Fisch, Masiak, Vismara i Block (2021) stwierdzili, że najważniejsze dla inwestorów są motywy technologiczne. Autorzy rozumieją przez nie entuzjazm inwestorów do technologii, którą wykorzystuje się w finansowanym przedsięwzięciu, oraz do jego modelu biznesowego lub też pomysłu, na którym się opiera. Nieco mniejsze, ale nadal istotne znaczenie mają motywy finansowe oraz ideologiczne. Te ostatnie, w podejściu przyjętym przez autorów badania, są związane z ideologią charakteryzującą sektor blockchain i ICO (Fisch i in., 2021). Zdarza się również, że w ICO uczestniczą inwestorzy z rynku venture capital (Block i in., 2020). 
Ostatnim etapem jest rozwój projektu opartego na technologii blockchain oraz wprowadzenie tokenów przez emitentów na platformy obrotu kryptoaktywami (gdzie odbywa się obrót wtórny tokenami) i przeprowadzanie market makingu w celu zapewnienia płynności (Liu i Wang, 2019b). Tokeny nie trafiają jednak natychmiast po ICO na platformę obrotu kryptoaktywami. Zwykle zajmuje to od tygodnia do sześciu miesięcy, choć może się okazać, że w ogóle nie będą na niej notowane (Feng, Li, Wong i Zhang, 2019).

\subsection{Analiza SWOT oferowania tokenów}

\section{Mocne strony i szanse}

ICO niesie ze sobą szereg potencjalnych korzyści zarówno dla emitentów tokenów, jak i dla inwestorów. ICO wspiera działania innowatorów i obniża wymogi dotyczące osobistego zaangażowania w tworzenie innowacji, ponieważ umożliwia przekazanie zdecentralizowanej sieci odpowiedzialności za jej rozwój. Ponadto jeśli tokeny stają się przedmiotem handlu na platformie obrotu kryptoaktywami, to innowatorzy mają możliwość szybkiego wyjścia z projektu poprzez ich sprzedaż (Momtaz, 2020).

ICO charakteryzuje się kosztami transakcyjnymi bliskimi zera (Howell i in., 2020; Momtaz, 2019). ICO są przeprowadzane przy wykorzystaniu inteligentnych kontraktów i bez udziału pośrednika. $Z$ tego względu marża, którą pobrałby pośrednik, może zostać rozdzielona między wszystkich właścicieli tokenów (Momtaz, 2019), również współtwórców platformy. Twórcy zdecentralizowanych platform, którzy dotychczas zwykle świadczyli swoje usługi nieodpłatnie (na przykład Wikipedia), mają więc zachętę do dalszego rozwoju platformy, ponieważ otrzymują środki finansowe. Ponadto posiadaczom tokenów zależy, aby platforma, którą wspierają, odniosła sukces. Są więc zmotywowani do jej wspierania, na przykład poprzez bezpośrednie użytkowanie tokenów, zgłaszanie pożądanych przez nich nowych funkcji czy znajdowanie błędów w funkcjonowaniu platformy (Howell i in., 2020).

ICO pomaga twórcom innowacji budować społeczność korzystających z niej podmiotów poprzez nagradzanie wczesnych użytkowników tokenami (Momtaz, 2020). Tokeny te mogą być rozprowadzane za darmo lub po niskiej cenie, dając pierwszym użytkownikom szansę na odniesienie korzyści finansowych wynikających z sukcesu platformy. Dostarczając tego typu bodźców finansowych, twórcy platformy rekompensują wczesnym użytkownikom jej ograniczoną użyteczność w początkowej fazie istnienia. Poza tym takie działania wzmacniają proces adaptacji i popularyzację platformy (Chen, 2018), a więc przyczyniają się do promocji marki (Howell i in., 2020). Tokeny mogą być również przyznawane aktywnym 
użytkownikom, aby zachęcić ich do częstszego korzystania z platformy (Chen, 2018). Ponadto ICO umożliwia oszacowanie popytu przyszłych użytkowników na produkty/usługi sprzedawane za pośrednictwem finansowanej platformy i wartość rynkową firmy już na wczesnym etapie jej istnienia (Howell i in., 2020).

W odniesieniu do inwestorów do niewątpliwych zalet ICO można zaliczyć między innymi umożliwienie (Chen, 2018; Momtaz, 2019):

- wszystkim ${ }^{8}$ inwestorom uczestnictwa $\mathrm{w}$ inwestycji na wczesnym etapie jej rozwoju - atrakcyjne możliwości inwestycyjne nie są zwykle dostępne w równym stopniu dla wszystkich inwestorów; tradycyjnie wyłącznie profesjonalni i akredytowani inwestorzy mieli możliwość inwestycji w projekty na tak wczesnym etapie ich rozwoju;

- demokratyzacji możliwości inwestycyjnych na świecie - inwestorzy z dowolnego miejsca na świecie mogą kupić większość tokenów, które są emitowane i sprzedawane nawet daleko od nich; z kolei większość tradycyjnych inwestycji typu venture jest silnie skoncentrowana pod względem geograficznym, co ogranicza wielu inwestorom możliwość ulokowania w nie środków; dzięki tokenom inwestorzy mogą inwestować w projekty na całym świecie i handlować tokenami z inwestorami z innych części globu;

- dywersyfikacji portfela inwestycyjnego ze względu na to, że notowania tokenów są obecnie słabo skorelowane z notowaniami aktywów tradycyjnych;

- odsprzedaży tokenów na platformie obrotu kryptoaktywami - podnosi to płynność tokenów i może przyciągnąć inwestorów, którzy mogliby unikać inwestycji z długim okresem ,zamrożenia” środków (lock-up period).

\section{Słabe strony i zagrożenia}

Zarówno potencjalni emitenci, jak i inwestorzy powinni mieć świadomość różnego rodzaju wad i zagrożeń związanych z ICO. Może się ono okazać nieopłacalne dla przedsiębiorców, jeśli projekt będzie rewolucyjny i odniesie sukces. Wynika to $\mathrm{z}$ tego, że dla projektu w początkowej fazie funkcjonowania organizowane jest tylko jedno ICO. Emitenci zwykle muszą sprzedać dużą część tokenów, gdy wycena projektu jest jeszcze niska (Chen, 2018). Występowanie tylko jednej rundy finansowania jest spowodowane tym, że podaż tokenów jest zwykle z góry ustalona (Klöhn i in., 2018). Oznacza to, że projekty nie mają szansy na kolejne rundy finansowania, w odróżnieniu od innych metod pozyskiwania środków, jak na przykład dzięki inwestycjom aniołów biznesu czy funduszy venture capital. Należy dodać, że ICO może się okazać nieoptymalne pod względem podatkowym

\footnotetext{
${ }^{8} \mathrm{Z}$ wyjątkiem wspomnianych wcześniej ograniczeń prawnych w dostępie do ICO inwestorów z poszczególnych państw.
} 
w porównaniu do metod finansowania za pomocą rynku kapitałowego, jeśli zgromadzone w ICO fundusze będą traktowane jako przychód lub odroczony przychód (Liu i Wang, 2019a).

Poza tym podmioty poszukujące finansowania muszą się liczyć z niepewnością odnośnie do kształtowania się regulacji, zwłaszcza w odniesieniu do tokenów inwestycyjnych (Chen, 2018). Brak lub niski poziom regulacji sprzyja występowaniu zagrożenia różnego typu oszustwami. Ich ofiarami mogą paść zarówno podmioty poszukujące finansowania (na przykład dokumentacja ich projektu - white paper może zostać splagiatowana), jak i inwestorzy (na przykład po pomyślnej sprzedaży tokenów emitenci mogą zniknąć ze zgromadzonymi środkami) (Ackermann, Bock i Bürger, 2020, za: Hartmann, Wang i Lunesu, 2018).

W przypadku utraty środków inwestorzy mogą mieć problem z ich odzyskaniem, między innymi dlatego, że trudno jest określić, dokąd wyprowadzone zostały fundusze (ze względu na pseudoanonimowość blockchainu') oraz ze względu na fakt, iż projekty ICO działają globalnie i nie jest jasne, czy i w jaki sposób krajowy organ nadzoru może wyciągnąć konsekwencje wobec nieuczciwych emitentów (Momtaz, 2020).

Zagrożenie stanowią również ataki phishingowe na strony ICO oraz ataki hakerskie na platformy obrotu kryptoaktywami i portfele kryptoaktywów (Ackermann $\mathrm{i}$ in., 2020, za: Hönig, 2018). Zgromadzone tam środki mogą zostać wówczas skradzione. Hornuf, Kück i Schwienbacher (2021) dochodzą do wniosku, że gdy kod programistyczny jest zamieszczony przez emitentów tokenów w serwisie GitHub, prawdopodobieństwo tego, że przedsięwzięcie padnie celem ataków phishingowych i hakerskich, jest większe. Oznacza to, że ujawnianie kodu źródłowego może się wiązać z ryzykiem. Autorzy stwierdzają, że na podstawie informacji dostępnych w momencie emisji tokenów niezwykle trudno jest przewidzieć, czy projekt okaże się oszustwem. Podkreślają potrzebę zaangażowania strony trzeciej, która mogłaby ocenić jakość emitentów. Mogłyby to być na przykład wyspecjalizowane platformy bądź fundusze venture capital, które są w stanie przeprowadzić due dilligence $\mathrm{i} \mathrm{w}$ ten sposób dokonać weryfikacji jakości projektu (Hornuf $\mathrm{i}$ in., 2021). Block i in. (2020) dodają, że tokeny inwestycyjne podlegają regulacjom dotyczącym papierów wartościowych i są chronione przez zabezpieczenie. $Z$ tego względu STO (security token offering) zapewnia dodatkowe zabezpieczenie przed oszustwem i manipulacją.

Należy również się liczyć z możliwością utraty całości zainwestowanych środków ze względu na wysokie ryzyko inwestycji w początkowej fazie istnienia.

\footnotetext{
${ }^{9}$ Pseudoanonimowość (również pseudonimowość) oznacza, że każdy użytkownik tokenu ma adres publiczny, na podstawie którego, przy pomocy właściwej analizy sieci, teoretycznie możliwe jest określenie IP jego komputera lub jego rachunku na platformie obrotu kryptoaktywami, a tym samym jego tożsamości (Bitcoin Magazine, 2020).
} 
Inwestorzy muszą przeprowadzić due dilligence przed ulokowaniem środków, co może być trudne ze względu na asymetrię informacji (Chen, 2018). Mogą przy tym korzystać $\mathrm{z}$ analiz publikowanych przez specjalnie prowadzone w tym celu strony internetowe. Należy jednak zauważyć, że występują znaczne rozbieżności w zakresie wyników tych ewaluacji oraz w przejrzystości samych stron internetowych, na których zamieszczane są wyniki analiz dotyczących ICO. Tego typu strony internetowe pobierają opłaty za publikację oceny ICO. Ponadto bardzo często zdarza się, że informacje dotyczące technicznych aspektów projektu nie są upubliczniane przez twórców projektu (Ackermann i in., 2020, za: Hartmann i in., 2018 i za: Cohney i in., 2019).

Asymetria informacji to zjawisko występujące dziś we wszystkich segmentach rynku finansowego i na rynkach klasycznych, i na rynku ICO. Rynki te różnią jednak źródła tej asymetrii. Jak zauważa Fisch (2019), ilość informacji dostępnych na temat ICO jest niska z powodu braku formalnych wymogów ujawniania informacji oraz ze względu na większą chęć zachowania anonimowości przez twórców projektu. Często zdarza się, że informacje, które inwestorzy biorą zwykle pod uwagę przy ocenie przedsięwzięć (na przykład życiorysy twórców projektu, historia przedsięwzięcia czy prognozy finansowe), są niedostępne w odniesieniu do ICO (Fisch, 2019). W przypadku regulowanych segmentów rynku finansowego dostęp do tego typu informacji jest zwykle łatwiejszy ze względu na nałożone prawnie na emitentów obowiązki informacyjne i kontrolę sprawowaną przez instytucje regulacyjne. Ponadto inwestor, lokując swoje środki na przykład w akcje spółki, ma do czynienia z papierami wartościowymi wyemitowanymi przez funkcjonujące już podmioty. Z tego względu oraz dzięki wspomnianym regulacjom i obowiązkom informacyjnym ocena przedsięwzięcia przez inwestora może być łatwiejsza niż w przypadku ICO. Jak zauważa Fisch (2019 za: Kaal and Dell'Erba, 2018), projekty finansowane poprzez sprzedaż tokenów są zwykle we wczesnej fazie rozwoju i mogą nie być w pełni funkcjonalne. Niewątpliwie fakt ten utrudnia ocenę projektu przez potencjalnych inwestorów i zwiększa asymetrię informacji.W przypadku obrotu tokenami na rynku wtórnym inwestorzy powinni pamiętać o tym, że kapitalizacja rynku tokenów jest niska, przez co duże zlecenia mogą mocno wpływać na cenę (Chen, 2018). Są również narażeni na manipulacje cenowe dokonywane przez dużych inwestorów czy osoby posiadające poufne informacje (Cohney i in., 2019). Ponadto niska płynność tokenów oraz dostępne obecnie rozwiązania w zakresie infrastruktury umożliwiającej bezpieczne przechowywanie tokenów mogą się okazać niewystarczające dla inwestorów instytucjonalnych (Ackermann i in., 2020, za: Labetzsch, 2018).

Powyższe rozważania mogą zostać podsumowane przy pomocy analizy SWOT. Mocne i słabe strony ICO i tokenów, a także szanse i zagrożenia dla tych innowacji zostały zestawione w tabeli 4.1. 
Tabela 4.1. Analiza SWOT ICO i tokenów

\begin{tabular}{|c|c|}
\hline Mocne strony & Slabe strony \\
\hline $\begin{array}{l}\text { - łatwość stworzenia tokenów na podstawie } \\
\text { ERC20 i możliwość modyfikacji wielu para- } \\
\text { metrów tokenów } \\
\text { - możliwość pozyskania środków na przepro- } \\
\text { wadzenie ICO z przedsprzedaży tokenów } \\
\text { - możliwość pozyskania informacji przydat- } \\
\text { nych do wyznaczenia ceny tokenu zapro- } \\
\text { ponowanej w ICO na podstawie informacji } \\
\text { zwrotnej od inwestorów zaangażowanych } \\
\text { w przedsprzedaż } \\
\text { - prosty przebieg ICO dzięki inteligentnym } \\
\text { kontraktom } \\
\text { - możliwość wyeliminowania pośredników } \\
\text { i obniżenia kosztów dzięki inteligentnym } \\
\text { kontraktom } \\
\text { - możliwość rozdzielenia marży, którą pobrał- } \\
\text { by pośrednik, między wszystkich właścicieli } \\
\text { tokenów }\end{array}$ & $\begin{array}{l}\text { - występowanie tylko jednej rundy } \\
\text { finansowania } \\
\text { - możliwość nieopłacalności ICO dla przed- } \\
\text { siębiorców, jeśli projekt okaże się rewolu- } \\
\text { cyjny i odniesie sukces (zbyt tania sprzedaż } \\
\text { tokenów) } \\
\text { - asymetria informacji - nieujawnianie przez } \\
\text { emitentów wszystkich informacji potrzeb- } \\
\text { nych inwestorom do oceny jakości projektu } \\
\text { - konieczność samodzielnego przeprowadze- } \\
\text { nia due dilligence przez inwestora } \\
\text { - ryzyko, że tokeny nie wejdą do obrotu na } \\
\text { platformę obrotu kryptoaktywami i wystąpią } \\
\text { związane z tym problemy z ich odsprzedażą } \\
\text { - możliwość utraty przez inwestorów całości } \\
\text { zainwestowanych środków ze względu na } \\
\text { wysokie ryzyko inwestycji w początkowej } \\
\text { fazie istnienia }\end{array}$ \\
\hline
\end{tabular}

- możliwość szybkiego wyjścia z projektu przez zaangażowane strony poprzez sprzedaż tokenów (w przypadku ich wejścia do obrotu na platformę obrotu kryptoaktywami)

- wsparcie rozwoju projektu przez posiadaczy tokenów, na przykład poprzez użytkowanie tokenów, zgłaszanie pożądanych przez nich nowych funkcji, znajdowanie błędów w funkcjonowaniu platformy

- możliwość oszacowania popytu przyszłych użytkowników na produkty/usługi sprzedawane za pośrednictwem finansowanej platformy i wartości rynkowej firmy już na wczesnym etapie jej istnienia

- możliwość budowania społeczności użytkowników platformy oraz promocji marki przez przyznawanie im tokenów

- możliwość dywersyfikacji portfela inwestycyjnego

\begin{tabular}{|c|c|}
\hline Szanse & Zagrożenia \\
\hline $\begin{array}{l}\text { - utrudniony dostęp do inwestycji na wcze- } \\
\text { snym etapie jej rozwoju dla inwestorów } \\
\text { indywidualnych (przy innych metodach } \\
\text { finansowania przedsięwzięć) } \\
\text { - koncentracja geograficzna projektów inwe- } \\
\text { stycyjnych na wczesnym etapie rozwoju }\end{array}$ & $\begin{array}{l}\text { - niepewność w zakresie regulacji ICO i obro- } \\
\text { tu tokenami } \\
\text { - niemożność udziału części inwestorów } \\
\text { w ICO ze względu na ograniczenia prawne } \\
\text { - niekorzystne dla emitentów rozwiązania } \\
\text { podatkowe - ICO może się okazać }\end{array}$ \\
\hline
\end{tabular}


Tabela $4.1-$ cd.

\begin{tabular}{|c|c|}
\hline Szanse & Zagrożenia \\
\hline $\begin{array}{l}\text { i trudny dostęp do nich dla inwestorów } \\
\text { (przy innych metodach finansowania } \\
\text { przedsięwzięć) } \\
\text { - większe zabezpieczenie inwestorów przed } \\
\text { oszustwem i manipulacją w przypadku STO } \\
\text { dzięki temu, że tokeny inwestycyjne zwykle } \\
\text { podlegają regulacjom dotyczącym papierów } \\
\text { wartościowych } \\
\text { - rosnąca popularyzacja kryptowalut, tokenów } \\
\text { i technologii blockchain }\end{array}$ & $\begin{array}{l}\text { nieoptymalne pod względem podatkowym } \\
\text { (jeśli zgromadzone w ICO fundusze będą } \\
\text { traktowane jako przychód lub odroczony } \\
\text { przychód) } \\
\text { - brak audytorów, którzy potwierdzaliby } \\
\text { prawdziwość informacji zawartych w white } \\
\text { paper } \\
\text { - ataki phishingowe na strony ICO oraz ataki } \\
\text { hakerskie na platformy obrotu kryptoakty- } \\
\text { wami i portfele kryptoaktywów } \\
\text { - oszustwa - w stosunku do emitentów } \\
\text { (na przykład plagiat white paper) lub in- } \\
\text { westorów (kradzież środków i ucieczka } \\
\text { emitentów) } \\
\text { - zróżnicowana jakość serwisów publikują- } \\
\text { cych ratingi ICO; ryzyko podjęcia decyzji } \\
\text { inwestycyjnej na podstawie nieprawidłowo } \\
\text { przeprowadzonej oceny przedsięwzięcia } \\
\text { - stosunkowo niska kapitalizacja i płynność } \\
\text { tokenów } \\
\text { ryzyko manipulacji cenowych na rynku } \\
\text { wtórnym tokenów }\end{array}$ \\
\hline
\end{tabular}

Źródło: opracowanie własne na postawie literatury przedmiotu przywołanej w rozdziale.

\subsection{ICO w badaniach literaturowych}

Wraz ze wzrostem popularności oferowania tokenów w ramach ICO wśród inwestorów i emitentów rośnie zainteresowanie tą problematyką ze strony pracowników nauki. Jeden z nurtów badań nad ICO dotyczy czynników sukcesu sprzedaży tokenów. Ustalenia autorów wskazują, że prawdopodobieństwo pomyślnego zakończenia ICO jest wyższe, gdy czas trwania ICO jest dłuższy (Samieifar i Baur, 2021), organizowana jest przedsprzedaż tokenów, udostępniony zostaje kod źródłowy projektu, a token daje użytkownikom dostęp do określonej usługi lub udział w zyskach (Adhami, Giudici i Martinazzi, 2018). Giudici i in. (2020) stwierdzają, że jeśli projekty są tworzone przez większe i bardziej doświadczone zespoły, to częściej powołują one komitet doradców. $Z$ kolei jego obecność jest istotnie i dodatnio skorelowana z sukcesem ICO. Howell i in. (2020) stwierdzają natomiast, że odsetek niepowodzeń ICO jest niższy, gdy osoby zaangażowane w tworzenie projektu nie mogą od razu sprzedać swoich tokenów (lock-up period), jeśli emitent uzyskał finansowanie venture $\mathrm{w}$ przeszłości lub gdy $\mathrm{CEO}$ /założyciel posiada 
doświadczenie w zakresie przedsiębiorczości lub informatyki. Ponadto odsetek ten jest niższy, gdy emitenci ujawniają informacje poprzez white paper i jeśli dokument ten określa, na co zostaną przeznaczone wpływy z ICO. Jednak zdaniem Adhamiego i in. (2018) dostępność dokumentacji projektu (white paper) nie jest związana z prawdopodobieństwem odniesienia sukcesu przez ICO. Dokumenty te cechują się zróżnicowaną ilością i jakością zawartych w nich informacji. Zdaniem autorów nie są one zbyt cenione przez potencjalnych uczestników ICO, zwłaszcza że ich jakość nie jest potwierdzana przez niezależnego audytora. Momtaz (2021a) zauważa natomiast, że emitenci tokenów wyolbrzymiają informacje, które są zawierane w white paper. Dzięki temu pozyskują więcej funduszy w krótszym czasie, co wskazuje na to, że inwestorzy początkowo nie dostrzegają tej praktyki. Odkrywają to z czasem, co może wywołać ich rozczarowanie. To z kolei może doprowadzić do spadku wartości tokenów i wzrostu prawdopodobieństwa niepowodzenia projektu. Adhami i in. (2018) uznają, że na sukces ICO ma silny wpływ dostępność kodów źródłowych (nawet ich części) w blockchainowym projekcie. Stanowi to bowiem namacalny dowód wykonalności projektu (proof-of-concept) dla potencjalnych nabywców tokenów. Nabywcy ci bowiem są dość obeznani $\mathrm{z}$ technologią (Adhami i in., 2018). To ostatnie stwierdzenie mogą jednak podważać wnioski Cohney'a i in. (2019), które zostały wysunięte na podstawie analizy kodów źródłowych związanych z tokenami. Autorzy ci stwierdzają, że obietnice składane przez twórców potencjalnym nabywcom tokenów nie znajdują odzwierciedlenia w kodzie źródłowym. Ponadto emitenci niektórych tokenów sprzedawanych w popularnych ICO zachowali możliwość zmiany praw wynikających z posiadania tych tokenów, jednak nie ujawnili tego faktu.

Wyniki badań literaturowych wskazują, że wysokość kwoty zebranej w wyniku ICO jest wyższa, jeśli twórcy projektu ujawniają informacje na swój temat (dotyczące wykształcenia, doświadczenia zawodowego, sieci kontaktów społecznych). Fakt ujawnienia tego typu danych jest również dodatnio powiązany z szybkością pozyskania środków w ICO (An, Duan, Hou i Xu, 2019). Samieifar i Baur (2021) stwierdzają, że im dłuższy czas trwania ICO, tym wyższa zebrana w jego wyniku kwota. Giudici i in. (2020) na podstawie swojej analizy dochodzą do wniosku, że na wysokość środków zgromadzonych w ICO ma wpływ sieć kontaktów, którą posiadają doradcy pracujący przy projekcie. Autorzy uznają, że w celu pozyskania większego finansowania ważne jest, aby zatrudniać doradców, w których sieci kontaktów znajdują się doradcy zatrudnieni przy innych ICO, również posiadający rozbudowaną sieć kontaktów. Dla wielkości pozyskanego finansowania znaczenie ma również aktywność emitentów na Twitterze w czasie trwania ICO (Fisch, 2019). Shrestha, Arslan-Ayaydin, Thewissen i Torsin (2021) zauważają natomiast, że projekty, które wywodzą się z państw o silniejszych instytucjach, pozyskują więcej środków. Zdaniem autorów może to wskazywać, że w obliczu zwiększonej 
niepewności i niewytworzonych ram prawnych regulujących funkcjonowanie ICO państwo macierzyste projektu może stanowić dla nich sygnał, na podstawie którego wnioskują o wiarygodności przedsięwzięcia. Ponadto Samieifar i Baur (2021) stwierdzają, że wysokość kwoty zebranej w ICO jest pozytywnie skorelowana z jego czasem trwania i stopniem, w jakim white paper jest czytelny dla odbiorcy (oryg. readibility of white paper).

Naukowcy poświęcają również swoją uwagę stopom zwrotu z tokenów sprzedawanych poprzez ICO. Benedetti i Kostovetsky (2021) zauważają znaczące niedoszacowanie tokenów w ICO. W analizowanej przez nich próbie średnia stopa zwrotu w pierwszym dniu po wprowadzeniu tokenów do obrotu na rynku wtórnym wyniosła 179\%. Zainteresowanie badaczy budzą również czynniki kształtujące stopy zwrotu z tokenów. Wyniki uzyskane przez Zhanga, Aertsa, Lu i Pana (2019) wskazują, że wyższa czytelność white paper wpływa na osiągnięcie wyższych stóp zwrotu w pierwszym dniu notowania tokenów na platformie. Z kolei Domingo, Piñeiro-Chousa i Ángeles López-Cabarcos (2020) stwierdzają, że występuje dodatnia relacja między stopami zwrotu z tokenów a stopami zwrotu z bitcoina i kontraktów terminowych na bitcoina oraz sentymentem inwestorów określonym na podstawie sieci społecznościowych. Zgodnie z ustaleniami autorów ujemny wpływ na stopy zwrotu z tokenów wywiera fakt wystąpienia ich przedsprzedaży. Fisch i Momtaz (2020) zauważają z kolei, że stopy zwrotu z tokenów po ICO są wyższe, jeśli tokeny mają wsparcie inwestorów instytucjonalnych. Autorzy uzasadniają to umiejętnościami inwestorów instytucjonalnych w zakresie wyboru odpowiednich projektów i radzenia sobie z asymetrią informacji na tym rynku.

\subsection{Podsumowanie}

Powstanie ICO i tokenów, na których podstawie jest ono przeprowadzane, stanowi kolejny etap wkraczania technologii blockchain do świata finansów. Technologia ta została stworzona wraz z bitcoinem i siecią, na której się on opiera. Obecnie bitcoin pełni przede wszystkim funkcję inwestycyjną i spekulacyjną. Jak wskazują rozważania przedstawione w tym rozdziale, tego typu zastosowanie mogą również mieć wykorzystywane w ICO tokeny. W wielu przypadkach mogą one odgrywać również inne role - użytkową i pozyskiwania finansowania. Przykład ICO wskazuje więc, że technologia blockchain może wspierać nie tylko działania inwestycyjno-spekulacyjne, ale również znaleźć zastosowanie w życiu gospodarczym i wspomagać procesy zachodzące w sferze realnej gospodarki - w przypadku zagadnień opisywanych w rozdziale, przede wszystkim przez umożliwienie zdobycia finansowania na rozwój platform dostarczających określone dobra lub usługi. 
ICO i tokeny mogą być nadal postrzegane jako innowacje i prawdopodobnie znajdują się obecnie na początkowym etapie rozwoju. W opinii autorki tego rozdziału to, czy przyjmą się na szerszą skalę, zależy od wielu czynników, spośród których najważniejszym są regulacje. Powinny one objąć nie tylko emitentów, ale również nabywców tokenów, tak by zapobiec materializacji pokusy nadużycia przez którąkolwiek ze stron. Możliwość ominięcia pośredników finansowych w przypadku ICO zmniejsza koszty jego przeprowadzenia. Niemniej jednak pokładanie zaufania wyłącznie w technologii blockchain i inteligentnych kontraktach w tym wypadku okazuje się niewystarczające, aby zapewnić bezpieczeństwo wszystkim uczestnikom każdego ICO. Wyeliminowanie pośredników finansowych, którzy często podlegają silnym regulacjom, wymaga wprowadzenia odrębnych przepisów prawnych, których podmioty zaangażowane w ICO muszą przestrzegać.

Ramy prawne nie powinny jednak zahamować rozwoju tej innowacji. Aby stworzyć tego typu regulacje, niezbędne jest zrozumienie mechanizmów rządzących ICO i pogłębienie dotychczasowych badań na ten temat. Poza tym ze względu na fakt, że ICO mogą być przeprowadzane w państwie innym niż to, z którego wywodzi się projekt, i mogą w nim uczestniczyć podmioty z różnych części świata, w odczuciu autorki niezwykle ważna jest międzynarodowa koordynacja wprowadzanych przepisów.

\section{Bibliografia}

Ackermann, E., Bock, C. i Bürger, R. (2020). Democratising entrepreneurial finance: the impact of crowdfunding and initial coin offerings ( ICOs ). W: A. Moritz, J. H. Block i S. Golla (Eds.), Contemporary developments in entrepreneurial finance. FGF studies in small business and entrepreneurship (s. 277-308). Cham: Springer. https://doi. org/10.1007/978-3-030-17612-9_11. Law Review. https://doi.org/10.2139/ssrn.3215345

Adhami, S. i Giudici, G. (2019). Initial coin offerings: tokens as innovative financial assets. https://doi.org/10.1007/978-3-030-25275-5_4

Adhami, S., Giudici, G. i Martinazzi, S. (2018). Why do businesses go crypto? An empirical analysis of initial coin offerings. Journal of Economics and Business, 100, 64-75. https://doi.org/10.1016/j.jeconbus.2018.04.001

An, J., Duan, T., Hou, W. i Xu, X. (2019). Initial coin offerings and entrepreneurial finance: the role of founders' characteristics. Journal of Alternative Investments, 21(4), 26-40. https://doi.org/10.3905/jai.2019.1.068

Antonopoulos, A. M. (2018). Bitcoin dla zaawansowanych. Programowanie z użyciem otwartego łańcucha bloków (wyd. 2). Gliwice: Helion.

Baur, D. G., Hong, K. H. i Lee, A. D. (2018). Bitcoin: medium of exchange or speculative assets?. Journal of International Financial Markets, Institutions and Money, 54, 177-189. https://doi.org/10.1016/j.intfin.2017.12.004 
Benedetti, H. i Kostovetsky, L. (2021). Digital tulips? Returns to investors in initial coin offerings. Journal of Corporate Finance, 66, 101786. https://doi.org/10.1016/j.jcorpfin.2020.101786

Bitcoin Magazine. (2020). Is bitcoin anonymous?. Pobrane $\mathrm{z}$ https://bitcoinmagazine.com/ what-is-bitcoin/is-bitcoin-anonymous

Block, J. H., Groh, A., Hornuf, L. i Vismara, S. (2020). The entrepreneurial finance markets of the future: a comparison of crowdfunding and initial coin offerings. Small Business Economics, 57, 865-882. https://doi.org/10.1007/s11187-020-00330-2

Chen, Y. (2018). Blockchain tokens and the potential democratization of entrepreneurship and innovation. Business Horizons, 61(4), 567-575. https://doi.org/10.1016/j. bushor.2018.03.006

Cohney, S., Hoffman, D., Sklaroff, J. i Wishnick, D. (2019). Coin-operated capitalism. Columbia Law Review, 119(3), 591-676. Pobrane z https://columbialawreview.org/ content/coin-operated-capitalism/

Dobrauz-Saldapenna, G. i Klebeck, U. (2019). Initial coin offering - legal and regulatory challenges of crossing the borders. Journal of Alternative Investments, 21(4), 81-94. https://doi.org/10.3905/jai.2019.21.4.081

Domingo, R. S., Piñeiro-Chousa, J. i Ángeles López-Cabarcos, M. (2020). What factors drive returns on initial coin offerings?. Technological Forecasting and Social Change, 153, 119915. https://doi.org/10.1016/j.techfore.2020.119915

EBC. (2015). Virtual currency schemes - a further analysis. Pobrane z https://www.ecb. europa.eu/pub/pdf/other/virtualcurrencyschemesen.pdf

Feng, C., Li, N., Wong, M. H. F. i Zhang, M. (2019). Initial coin offerings, blockchain technology, and white paper disclosures. http://dx.doi.org/10.2139/ssrn.3256289

Fisch, C. (2019). Initial coin offerings (ICOs) to finance new ventures. Journal of Business Venturing, 34(1), 1-22. https://doi.org/10.1016/j.jbusvent.2018.09.007

Fisch, C., Masiak, C., Vismara, S. i Block, J. (2021). Motives and profiles of ICO investors. Journal of Business Research, 125, 564-576. https://doi.org/10.1016/j.jbusres. 2019.07.036

Fisch, C. i Momtaz, P. P. (2020). Institutional investors and post-ICO performance: an empirical analysis of investor returns in initial coin offerings (ICOs). Journal of Corporate Finance, 64, 101679. https://doi.org/10.1016/j.jcorpfin.2020.101679

Giudici, G., Giuffra Moncayo, G. i Martinazzi, S. (2020). The role of advisors' centrality in the success of initial coin offerings. Journal of Economics and Business, 112, 105932. https://doi.org/10.1016/j.jeconbus.2020.105932

Hartmann, F., Wang, X. i Lunesu, M. I. (2018). Evaluation of initial cryptoasset offerings: the state of the practice: IWBOSE 2018. IEEE international workshop on blockchain oriented software engineering. Pobrane $\mathrm{z}$ http://ieeexplore.ieee.org/servlet/opac?punumber $1 / 48323138$

Hornuf, L., Kück, T. i Schwienbacher, A. (2021). Initial coin offerings, information disclosure, and fraud. Small Business Economics. https://doi.org/10.1007/s11187-021$00471-y$

Houben, R. i Snyers, A. (2018). Cryptocurrencies and blockchain. Legal context and implications for financial crime, money laundering and tax evasion. Parlament Europejski. https://doi.org/10.2861/263175 
Howell, S. T., Niessner, M. i Yermack, D. (2020). Initial coin offerings: financing growth with cryptocurrency token sales. The Review of Financial Studies, 33(212), 3925-3974. https://doi.org/10.1093/rfs/hhz131

Huang, W., Meoli, M. i Vismara, S. (2020). The geography of initial coin offerings. Small Business Economics, 55(1), 77-102. https://doi.org/10.1007/s11187-019-00135-y

Klöhn, L., Parhofer, N. i Resas, D. (2018). Initial coin offerings (ICOs). Economics and Regulation. Pobrane z https://papers.ssrn.com/sol3/papers.cfm?abstract_id=3290882

Kubát, M. (2015). Virtual currency bitcoin in the scope of money definition and store of value. Procedia Economics and Finance, 30, 409-416.

Lehman, A. (2016). Building the trust engine. How the blockchain could transform finance (and the world). UBS. Pobrane $\mathrm{z}$ https://www.ubs.com/microsites/news-for-banks/en/ products-and-services/2016/building-the-trust-engine.html

Liu, C. i Wang, H. (2019a). Crypto tokens and token offerings: an introduction. W: S. S. Goutte i K. Guesmi (Eds.), Cryptofinance and mechanisms of exchange. Contributions to management science (s. 125-144). Cham: Springer. https://doi.org/10.1007/978-3030-30738-7_8

Liu, C. i Wang, H. (2019b). Initial coin offerings: what do we know and what are the success factors ? W: S. S. Goutte S. i K. Guesmi (Eds.), Cryptofinance and mechanisms of exchange. Contributions to management science (s. 145-164). Cham: Springer. https:// doi.org/10.1007/978-3-030-30738-7_9

Marszałek, P. (2019). Kryptowaluty - pojęcie, cechy, kontrowersje. Studia BAS, 1(57), 105-25. https://doi.org/10.31268/StudiaBAS.2019.06

Momtaz, P. P. (2019). Token sales and initial coin offerings: introduction. Journal of Alternative Investments, 21(4), 7-12. https://doi.org/10.3905/jai.2019.21.4.007

Momtaz, P. P. (2020). Initial coin offerings. PLoS ONE, 15(5), e0233018. https://doi. org/10.1371/journal.pone.0233018

Momtaz, P. P. (2021a). Entrepreneurial finance and moral hazard: evidence from token offerings. Journal of Business Venturing, 36(5), 1-24. https://doi.org/10.1016/j.jbusvent.2020.106001

Momtaz, P. P. (2021b). Initial coin offerings, asymmetric information, and loyal CEOs. Small Business Economics, 57, 975-997. https://doi.org/10.1007/s11187-020-00335-x

OECD. (2019). Initial coin offerings (ICOs) for SME financing. Pobrane z www.oecd.org/ finance/initial-coin-offerings-for-sme-financing.htm

Nakamoto, S. (2008) Bitcoin: a peer-to-peer electronic cash system. Pobrane z https:// bitcoin.org/bitcoin.pdf

Piech, K. (red.). (2016). Leksykon pojęć na temat technologii blockchain i kryptowalut. Strumień ,, Blockchain i Kryptowaluty” programu ,, Od papierowej do cyfrowej Polski”. Pobrane z https://www.gov.pl

Rhue, L. (2018). Trust is all you need: an empirical exploration of initial coin offerings (ICOs) and ICO reputation scores. http://dx.doi.org/10.2139/ssrn.3179723

Samieifar, S. i Baur, D. G. (2021). Read me if you can! An analysis of ICO white papers. Finance Research Letters, 38, 101427. https://doi.org/10.1016/j.frl.2020.101427

Shrestha, P., Arslan-Ayaydin, Ö., Thewissen, J. i Torsin, W. (2021). Institutions, regulations and initial coin offerings: an international perspective. International Review of Economics and Finance, 72, 102-120. https://doi.org/10.1016/j.iref.2020.10.014 
Sławiński, A. (2019). Kryptowaluty - zapowiedzi i rzeczywistość. W: W. Przybylska-Kapuścińska i K. Perez (red.), Polityka pieniężna i rynki finansowe wobec wyzwań gospodarki 4.0. Warszawa: CeDeWu.

Włosik, K. (2021). Rynek kryptowalut i tokenów z perspektywy inwestycyjnej. Poznań: Wydawnictwo Uniwersytetu Ekonomicznego w Poznaniu. https://doi.org/10.18559/97883-8211- 081-4

Zhang, S., Aerts, W., Lu, L. i Pan, H. (2019). Readability of token whitepaper and ICO first-day return. Economics Letters, 180, 58-61. https://doi.org/10.1016/j.econlet.2019.04.010 